\title{
Kişilik Özelliklerinin Finansal Risk Toleransı Üzerindeki Etkisi: Üniversite Öğrencileri Üzerine Bir Araştırma*
}

Kezban HITAY*

Adem ANBAR**

\begin{abstract}
ÖZET
Bu çalışmanın amacı, bireylerin beş faktör kişilik özellikleri ile finansal risk toleransları arasındaki ilişkinin incelenmesidir. Bu kapsamda, Bursa Uludă̆ Üniversitesi İktisadi ve İdari Bilimler Fakültesi'nde üçüncü ve dördüncü sınıflarda okuyan ögrencilerden anket tekniği kullanılarak veri toplanmıştır. Verilerin analizinde tanımlayıc istatistikler, t-testi, tek yönlü varyans analizi (ANOVA) ve hiyerarşik regresyon analizi kullanılmıştır. Yapılan analizler sonucunda, demografik özelliklerden cinsiyet, gelir ve bölüm değişkenlerine göre katılımcıların finansal risk toleransı düzeyleri arasında istatistiksel olarak anlamlı bir farklılığın olduğu ve beş faktör kişilik özelliklerinden deneyime açıklık boyutu ile finansal risk toleransı arasında anlamlı ve pozitif bir ilişkinin olduğu bulgularına ulaşılmıştır.
\end{abstract}

Anahtar Kelimeler: Risk, Finansal Risk Toleransı, Kişilik Özellikleri.

JEL Sınıflandırması: G40, G41

The Effect Of Personality Traits On Financial Risk Tolerance: An Investigation On University Students

\section{ABSTRACT}

The aim of this study is to examine the relationship between individuals' five-factor personality traits and financial risk tolerances. In this context, data was collected from the students studying in the third and fourth classes at the Faculty of Economics and Administrative Sciences at Bursa Uludag University using the survey technique. Descriptive statistics, t-test, one-way analysis of variance (ANOVA) and hierarchical regression analysis were used in the analysis of the data. As a result of the analyzes, it was found that there was a statistically significant difference between the financial risk tolerance levels of the participants according to gender, income, and department variables, and there was a significant positive relationship between the openness to experience a dimension of five-factor personality traits and financial risk tolerance.

Keywords: Risk, Financial Risk Tolerance, Personality Traits.

Jel Classification: G40, G41

\footnotetext{
* Makale Gönderim Tarihi: 10.12.2019,Makale Kabul Tarihi: 20.01.2020, Makale Türü: Nicel Araştırma

* Öğr. Gör., Kütahya Dumlupınar Üniversitesi, Simav Meslek Yüksekokulu, kezban.hitay@dpu.edu.tr , ORCID ID: 0000-0002-8057-1780.

**Doç.Dr., Bursa Uludağ Üniversitesi, İktisadi ve İdari Bilimler Fakültesi, aadem@uludag.edu.tr, ORCID-ID: 0000-0001-8909-6851.
} 


\section{GíRiş}

Finansal karar alma sürecinde önemli girdilerden biri olarak kabul edilen finansal risk toleransı, bireylerin finansal karar alırken kabul edebileceği maksimum belirsizlik miktarı olarak tanımlanabilir (Dinç Aydemir ve Aren, 2016:76). Bireylerin finansal riske karşı tutumları; tasarruf, yatırım, çeşitlendirme, sigorta, emeklilik planlaması gibi birçok alanda alacakları kararlarda etkili olmaktadır. Dolayısıyla bireylerin finansal risk toleransı düzeylerine göre alacakları finansal kararların kendi finansal refahları üzerinde etkileri olacağı gibi, finansal piyasalar ve ekonominin geneli üzerinde de etkileri olacaktır (Fisher ve Yao, 2017:191). Finansal risk toleransı, özellikle belirsizliğin veya riskin yüksek olduğu finansal piyasalarda daha da önemli hale gelmektedir (Gilliam vd., 2010: 40). Finansal risk toleransı yüksek olan bireylerin finansal piyasalardaki düşüş veya yükselişlerde belirsizliği daha iyi tolere edebilecekleri ve süreci daha iyi yönetebilecekleri kabul edilmektedir (Chaulk vd., 2003:258; Fisher ve Yao, 2017:191). Bu gibi nedenlerle, bireylerin finansal risk toleranslarının ölçülmesi ve finansal risk toleransını etkileyen faktörlerin belirlenmesi, sadece araştırmacılar tarafından değil, portföy yöneticileri, yatırım danışmanları gibi uygulayıcılar ve politika yapıcılar tarafindan da ilgi gösterilen bir konu olmuştur.

Finansal risk toleransını yaş, cinsiyet, medeni durum, eğitim düzeyi gibi demografik faktörler; gelir, servet, çalışma durumu, ev sahipliği gibi ekonomik faktörler; kişsilik özellikleri, tutum ve inanışlar gibi psikolojik faktörler etkilemektedir (Grable ve Joo, 2004: 74; Yao ve Hanna, 2005: 66; Van de Venter vd., 2012: 94; Kuzniak ve Grable, 2017: 320). Bunların dışında, finansal kararlara yönelik geçmişte yaşanmış deneyim ve tecrübeler, finansal piyasaların geleceğine yönelik beklentiler ve kültür de bireylerin finansal risk toleransları üzerinde etkili olmaktadır (Kourtidis vd., 2017: 1404). Görüleceği gibi, finansal risk toleransını etkileyen birçok faktör vardır, diğer bir deyişle, finansal risk toleransı çok boyutlu bir yapıya sahiptir.

Bireylerin finansal kararlar alırken kendi kişilik özelliklerini ve olası psikolojik önyargılarını göz önünde bulundurmaları, doğru karar almalarında önemli bir rol oynayacaktır (Jameel ve Siddiqui, 2019:2). Ayrıca, kişilik özelliklerinin finansal risk toleransı ve dolayısıyla finansal kararlar üzerindeki etkisinin ortaya konulmaya çalışılması, portföy yöneticilerinin ve yatırım danı̧̧manlarının müşterileri adına daha doğru kararlar almalarına ve/veya onların finansal amaç ve beklentilerine daha uygun tavsiyelerde bulunmalarına yardımcı olacaktır.

Bu çalışmanın amacı, kişilik özelliklerinin finansal risk toleransı üzerindeki etkilerini belirlemeye yöneliktir. Çalışmanın bundan sonraki kısmı dört bölümden oluşmaktadır. İlk bölümde, finansal risk toleransı kavramı ile beş faktör kişilik modeli açıklanmıştır. İkinci bölümde, kişilik özellikleri ile finansal risk toleransı arasındaki ilişkiye yönelik literatür ortaya konulmaya çalışılmıştır. Üçüncü bölümde çalışmanın metodolojisine ve dördüncü bölümde bulgulara yer verilerek çalışma tamamlanmıştır. 


\section{KAVRAMSAL ÇERÇEVE}

\subsection{Finansal Risk Toleransı}

Fransızca kökenli "risgue" kelimesinden gelen riskin Türk Dil Kurumu (TDK) Sözlüğü’ndeki anlamı, "bir zarara, bir kayba uğrama tehlikesi”dir. Risk kavramı farklı bilim dallarında farklı şekillerde tanımlanmaktadır. Finansal anlamda risk, bir işleme ilişkin parasal kaybın veya bir zararın ortaya çıkması ile sonuçlanabilecek ekonomik faydanın azalma olasılığı olarak tanımlanabilir (Demireli, 2007:123). Bireylerin finansal bir takım riskli durumlar karşısındaki risk alma tutumunu gösteren finansal risk toleransı ise, bir bireyin finansal karar verirken kabul edebileceği maksimum belirsizlik miktarını ifade etmektedir. (Grable, 2000:625). Finansal risk toleransı, riskten kaçınma eğiliminin karşıt anlamlısıdır (Hallahan vd., 2003:484). Diğer bir ifadeyle, finansal risk toleransı düşük (yüksek) olan bireylerin riskten kaçınma eğilimi daha yüksektir (düşüktür).

Yüksek ve düşük risk toleransına sahip bireylerin davranışları birbirinden farklılık göstermektedir. Düşük finansal risk toleransına sahip bireyler, genel olarak, finansal bir faaliyet gerçekleştirdiklerinde daha az zarar görmek istemektedirler. Bunun yanında yüksek belirsizlik durumunda faaliyetten kaçınarak gerçekleştirecekleri faaliyetler hakkında daha fazla bilgi sahibi olmak istemektedirler. Yüksek finansal risk toleransına sahip bireyler ise, düşük risk toleransına sahip bireylere göre, kendilerine daha fazla güvenmekte ve zararı göze alabilmektedirler (Anbar ve Eker, 2009: 132). Finansal risk tolerans1 yüksek olan bireyler, portföylerinde hisse senedine daha fazla yer vermekte ve finansal piyasalarda daha sık işlem yapmaktadırlar. Bu kişiler, riski daha fazla göze aldıkları için, portföy çeşitlendirmesine daha az önem verebilmektedirler (Dorn ve Huberman, 2005:437; Hoffmann vd., 2015:98; Kourtidis vd., 2017: 1405).

Bireylerin içerisinde bulundukları durumlar, yaşam tarzları, yetiştirilme şartları, kişilik özellikleri farklı olduğu için, risk her birey tarafından farklı düzeyde algılanmaktadır. Dolayısıyla, yapılması planlanan veya düşünülen bir yatırımın risk seviyesi her birey için farklı düzeyde algılanacağından bireylerin verecekleri kararlar da farklılık gösterecektir. Duruma göre az riskli olarak kabul edilebilen, başka bir durumda çok riskli olarak kabul edilebilecek, bireyler de aynı durumu az ya da çok riskli olarak değişik düzeylerde algılayabileceklerdir. Diğer bir deyişle, farklı bireyler bir durumu farklı risk düzeyinde algılayabilecekleri gibi, bir birey de farklı durumlarda aynı risk düzeyini farklı algılayabilecektir (Ceyhan, 2008: 3). Bu durum kişiliğin riskin algılanmasında son derece önemli bir unsur olduğunu ortaya koymaktadır.

\subsection{Kişilik Ve Beş Faktör Kişilik Modeli}

Kişilik, genel olarak, bir bireyi diğer bireylerden ayıran, onu diğerlerinden farklı kılan kendine has özellikler bütünü olarak ifade edilebilir (İçerli ve Arsu, 2019: 22). Kişilik, doğuştan gelen ve bireyi diğer insanlardan ayıran mizacın ve farklı durumlarda ortaya çıkan özelliklerin birleşimidir (Horzum vd., 2017: 398). Kişilik özellikleri, bir bireyin diğer bireylerden duygu, düşünce ve davranış yönünden ayırt edilmesini sağlayan, belirli koşullar altında gösterdikleri kendine has, ayırt edici davranış eğilimlerini yansıtan özelliklerdir (Roberts, 2009: 139). Doğuştan gelen biyolojik ve psikolojik özelliklerin yanında, kişilik 
bireylerin sosyal hayatta ve eğitimle kazandıkları yetenekleri, güdüleri, tutumları ve mizaç özelliklerini de içermektedir (Paksoy vd., 2019: 3864).

Kişilik kavramına ilişkin genel kabul görmüş bir tanımlama yapılamamış olmasına rağmen, kişilik alanında yapılan bilimsel çalışmalar neticesinde araştırmacılar tarafından kişiliğin kapsamlı bir değerlendirmesi olduğu hususunda kanaat getirilen bir model ortaya konulmuştur. $\mathrm{Bu}$ model beş faktör kişilik modelidir (Golberg, 1990). Beş faktör kişilik modeli, dil hipotezine dayanmaktadır. İnsanlarda gözlemlenen bireysel farklılıkların tüm dünyanın ortak dili olarak kodlanacağı ve bu sözcükler vasıtasıyla konuşma diline yansıyacağı, bunun sonucunda ise bireyin kişilik yapısını kapsayacak bir sınıflama oluşturulabileceği ifade edilmektedir (Çelebi ve Uğurlu, 2014: 540). İlk olarak F. Galton tarafından 1884 yılında bireysel farklılıkları ortaya koymak amacıyla çeşitli sözcükler önerilmiş ve daha sonraki yıllarda G. W. Allport ve H. S. Odbert'in (1936) bu konudaki çalışmaları devam etmiştir. Bu çalışmalardan yola çıkan R. Cattell ise 1957'de 16 kişilik faktörünü oluşturmuştur (İçerli ve Arsu, 2019: 23). W. Norman, 1963 yılında gerçekleştirdiği çalışmasında, 20 ölçekli bir dereceleme ölçeğine faktör analizi uygulayarak beş temel faktör haline getirmiştir (Deniz ve Erciş, 2008: 303). 1970'lerin sonları ve 1980'lerin başlarında P. T. Costa ve R. R. McCrae yapmış oldukları çalışmalarla beş faktör kişilik modelini geliştirmişlerdir (Çelebi ve Uğurlu, 2014: 540).

Psikoloji ve sosyoloji başta olmak üzere birçok alanda kabul gören ve yaygın bir şekilde kullanılan beş faktör kişilik modeli, kişiliği beş temel boyut altında toplamaktadır. Bu beş boyut veya faktör; dışa dönüklük, uyumluluk, sorumluluk, duygusal denge/dengesizlik (nörotizm) ve deneyime açıklıktır. Model, "büyük beşli" olarak da ifade edilen bu kişilik faktörlerini, kişilik hiyerarşisinin en üst seviyesine yerleştirmekte ve modelin, bu faktörlerin hiyerarşinin daha düşük seviyelerinde yer alan daha dar kişilik özelliklerinin tüm alanını kapsadığı kabul edilmektedir (Dinç vd., 2013: 50). Beş faktör kişilik modelinin temelde iki özelliği mevcuttur (Costa vd., 1991). Birincisi, beş faktör kişilik modelinin net ve kavramsal değerlere dayanması, ikincisi ise, bu beş faktörün kişiler arasındaki farklılıkları net bir şekilde belirleyebilmesidir.

Beş faktör kişilik özellikleri aşağıda kısaca açıklanmıştır.

Dışa Dönüklük: Dışa dönük bir kişilik yapısına sahip olan bireyler; iddialı, diğer bireylerle kolay iletişim kuran, olumlu düşünen, enerji dolu, girişken ve konuşkan kişiliğe sahip insanlardır (Eroğluer ve Kahraman, 2019: 22). Dışa dönüklük faktörü; sıcakkanlılık, insan canlısı olma durumu, girişkenlik, hareketlilik, heyecan arayışı ve pozitif duygu durumu gibi ölçütlerle belirlenebilir (Howard ve Howard, 1998). Özellikle iş ortamında amaca yönelik bir tutum içerisinde olan bu kişilik yapısına sahip bireyler, iş ortamında pozitif bir sosyal çevreyi tecrübe ederler (Dinç vd., 2013: 51). İş hayatında pozitif sosyal çevre içerisinde bulunan bireyler, çalışma arkadaşlarına pozitif enerji verdikleri için de pozitif tepki alırlar (Alarcon vd., 2009: 246). İçe dönük bireyler, dışa dönük olanların tersine, düşük yaşam enerjisine ve genellikle negatif düşünce yapısına sahiptirler. İçe dönük bireyler sessizdirler, sosyal dünya ile ilgilenmezler ve tedbirli davranıştan yanadırlar (Deniz ve Erciş, 2008: 304).

Uyumluluk: Bireyin çevresindeki diğer kişilerle beraber hareket edebilme becerileri olarak ifade edilen uyumluluk (yumuşak başlılık) faktörü, dürüstlük, diğer insanları düşünme, cömertlik, kibarlık, hoşgörülü olma, fedakarlık, uyumluluk, merhametlilik, alçak gönüllülük 
gibi değerleri yansıtan bir kişilik faktörüdür (Tatar vd., 2014:185). Uyumluluk faktörü, diğer bireylerle ilgili olmayı ifade eden bir özelliktir. Yardıma ihtiyaç duyanlarla ilgilenmeyi, mutsuzluk oluşturan durumların çözümünde yardımlaşmayı ifade etmektedir (Dinç vd., 2013: 52). Uyumluluk faktörünün bir ucunda şefkat, fedakarlık, duygusal destek vb. olumlu özellikler yer alırken, diğer tarafında ilgisizlik, düşmanlık, benmerkezcilik, kıskançlık gibi olumsuz özellikler yer almaktadır (İçerli ve Arsu, 2019: 24).

Sorumluluk: Sorumlu bireyler disiplinli, düzenli, kendileri ve başkaları için sorumluluk alabilen, gerçekçi ve bir işe adım atmadan önce iyi düşünen bireylerdir. Bunlara ilave olarak başarı odaklı, her türlü görevde başarı kazanma olasılıkları yüksek, çalışkan kişilerdir. Sorumluluk sahibi bireyler sorunla karşılaş̧ma ihtimallerini göz önünde tutarak her zaman hazırlıklı, etik ilke ve değerlere belirgin bir şekilde bağlı, başladıkları bir işi sonuca ulaştırabilme becerisine sahip bireyler olma eğilimindedirler. Onların sorumluluğu ve güçlü kararlılık duyguları hedeflerine başarıyla ulaşmalarına yardımcı olur ve üstlerinin takdirini kazanmalarını sağlar (Nitelik Ödemiş, 2011: 84). Sorumluluk, bireylerin dürtülerini nasıl kontrol ettiğini ifade etmektedir. Sorumluluk özelliğine yüksek düzeyde sahip olan bireylerin çatışmaya girme olasılıkları daha düşüktür (Paksoy vd., 2019: 3865)

Duygusal Denge/Dengesizlik (Nevrotiklik): Nevrotiklik, duygusal dengeye karşı uyumu gösterir. Yüksek nevrotiklik özelliğine sahip bireyler, yüksek düzeyde anksiyete, düşmanlık, depresyon ve içe kapalılık özelliklerini göstermektedirler (Seibert ve Kraimer, 2001: 3). Bu faktör, nevrotik özelliklere sahip bireylerin endişeli, güvensiz, kendisiyle uğraşan, sinirli, kaygılı bir yapıda olacaklarını ve stres ile baş etmede zorlanacaklarını ifade etmektedir (Somer vd., 2002: 23). Nevrotiklik düzeyi düşük bireyler ise dengeli, sakin bir yapıya sahiptirler ve stresle güçlü bir şekilde baş edebilmektedirler (Horzum vd., 2017: 400).

Deneyime Açıklık: Beşinci ve son faktör olan deneyime açıklık; macerayı, sıra dışı fikirleri, hayal gücünü, merakı ve çeşitli deneyimleri içinde barındıran bir kişilik faktörüdür. $\mathrm{Bu}$ özelliğe sahip bireyler, basmakalıp bireylerden ayrılmakta, kapalı bireylere göre daha yaratıı ve arzularının daha fazla farkında olan bireylerdir. Ayrıca entelektüel, sanatı takdir eden, estetiğe duyarlı kişilerdir (Temeloğlu ve Karaman, 2014: 453). Değişime karşı direnç gösterme, yeni fikirlere kapalı olma, ilgisiz ve meraksız olma gibi özellikler ise, deneyime açıklık düzeyi düşük olan bireylerin başlıca özellikleridir (Erkuş ve Tabak, 2009: 216).

\section{LITERATÜR}

Bireylerin finansal risk toleransı düzeylerini ölçmeye ve finansal risk toleransını etkileyen faktörleri belirlemeye yönelik çalı̧̧malar, özellikle 1980'li y1llardan itibaren artmaya ve önem kazanmaya başlamıştır. Demografik, sosyo-ekonomik, psikolojik ve çevresel faktörler gibi finansal risk toleransını etkileyen birbiriyle ilişkili birçok faktör olmakla birlikte, yapılan çalş̧̧alar demografik ve sosyo-ekonomik faktörler üzerinde yoğunlaşmıştır. Son yıllarda ise, psikolojik faktörlerin altında yer alan kişilik özelliklerinin bireylerin finansal risk toleransları üzerindeki etkilerini incelemeye yönelik çalışmalar da yapılmaya başlanmıştır. Burada, kişilik özellikleri ile finansal risk toleransı arasındaki ilişkileri inceleyen çalışmalardan bazılarının bulgularına yer verilmeye çalışılmıştır.

Wong ve Carducci (2013), psikoloji ve finans bölümlerinde okuyan üniversite öğrencileri üzerine yaptıkları çalışmalarında, beş faktör kişilik özellikleriyle finansal risk 
toleransı arasındaki ilişkiyi incelemişlerdir. Çalışmada, dışa dönüklük ve deneyime açıklık kişilik özelliklerinin finansal risk toleransı üzerinde pozitif bir etkiye, sorumluluk ve uyumluluk kişilik özelliklerinin ise negatif bir etkiye sahip olduğu bulgularına ulaşılmıştır. Pak ve Mahmood (2013), potansiyel yatırımcıların kişilik özellikleri, risk alma tutumları ve yatırım kararları arasındaki ilişkiyi incelemişlerdir. Araştırma sonucunda, kişilik özelliklerinin bireyin risk toleransı üzerinde bir miktar etkiye sahip olduğu ve bunun da hisse senedi, tahvil ve diğer menkul kıymetlerle ilgili yatırım kararlarını etkilediği bulgusuna ulaşılmıştır. Ayrıca, beş faktör kişilik özellikleri bağlamında, deneyime açıklık boyutunun risk toleransı üzerinde pozitif, uyumluluk boyutunun ise negatif bir etkiye sahip olduğu bulgusuna da ulaşılmıştır. Pinjisakikool (2017), bireylerin kişilik özelliklerinin finansal risk toleransı aracılığıyla finansal davranışları üzerindeki etkilerini incelemiştir. Çalışmada, beş faktör kişilik boyutlarından dışa dönüklük ve deneyime açıklığın finansal risk toleransıyla pozitif, sorumluluk, uyumluluk ve duygusal denge/dengesizlik boyutlarının ise finansal risk toleransıyla negatif ilişkili olduğu ve kişilik özelliklerinin finansal risk toleransı aracılığıyla finansal davranışlar üzerinde dolaylı bir etkisinin olduğu bulgularına ulaşılmıştır. Dickason ve Ferreira (2018) risk toleransı, yatırımcı kişiliği ve davranışsal finans arasındaki ilişkileri tespit etmeye çalışmışlardır. Çalışmanın bulguları, düşük risk toleransı seviyesine ve muhafazakar bir yatırımcı kişiliğine sahip yatırımcıların zararı önleme ve zihinsel muhasebe önyargılarına daha fazla maruz kaldıklarını göstermektedir. Yüksek risk toleransına sahip yatırımcıların ise çoğunlukla öz denetim yanlılığına maruz kaldığı tespit edilmiştir. Baffour vd. (2018), riskten kaçınma eğiliminde cinsiyetin rolünü ve kişilik özelliklerinin riskten kaçınma eğilimi üzerindeki etkisini incelemişlerdir. Çalışmada, kadınların erkeklere göre daha fazla riskten kaçınma eğilimine sahip oldukları ve beş faktör kişilik özelliklerinden sorumluluk ve duygusal denge/dengesizlik boyutlarının riskten kaçınma eğilimi üzerinde pozitif yönde bir etkiye sahip oldukları bulgularına ulaşılmıştır. Anastasia ve Mamelak (2019), Endonezya'da yatırımcılar üzerine gerçekleştirdikleri çalışmada kişilik özelliklerinin finansal risk toleransı üzerindeki etkisini belirlemeye çalışmışlardır. Çalışmada, sansasyon arayışı ve belirsizlik toleransının finansal risk toleransını önemli ölçüde etkilediği, kontrol odağı faktörünün ve öz kontrol becerisinin finansal risk toleransı üzerinde bir etkisinin olmadığı bulunmuştur. Czerwonka (2019), bireylerin kültürel, bilişsel ve kişilik özelliklerine göre riske olan duyarlılıklarını ölçmek amacıyla Amerika Birleşik Devletleri (ABD) ve Polonya'daki lisans öğrencileri üzerine bir araştırma gerçekleştirmiştir. Araştırma sonucunda, Polonyalı öğrencilerin Amerikalı öğrencilere göre daha fazla risk alma eğilimine sahip oldukları, dişa dönük bireylerin risk alma eğilimlerinin daha yüksek, sorumlu bireylerin ise risk alma eğilimlerinin daha düşük olduğu bulgularına ulaşılmıştır. Jameel ve Siddiqui (2019), Pakistan Menkul Kıymetler Borsası'nda işlem yapan 150 bireysel yatırımcı üzerinde bir araştırma yapmışlar ve çalışmada kişilik özellikleri, finansal okuryazarlık gibi çeşitli faktörlerin risk toleransı ve psikolojik yanlılıklar üzerindeki etkilerini araştırmışlardır. Risk toleransı açısından, dışa dönüklük kişilik özelliği ile hem bulunabilirlik ve aşırı güven yanlılığı hem de risk toleransı arasında anlamlı bir ilişki olduğu ve risk toleransının çapa yanlılığını ve kumarbaz yanılgısını etkilediği sonucuna ulaşılmıştır. Rabbani vd. (2019), ABD'de yaşayan 54-61 yaş aralığındaki bireyler üzerine yaptıkları çalışmada, beş faktör kişilik özellikleri ile finansal risk toleransı arasındaki ilişkiyi incelemişlerdir. Çalışmada, dışadönüklük, duygusal denge/dengesizlik ve deneyime açıklık kişilik özelliklerini daha fazla taşıyanların daha yüksek risk toleransına sahip oldukları, uyumluluk ve sorumluluk kişilik özelliklerini daha fazla taşıyanların ise daha düşük risk toleransına sahip oldukları sonucuna ulaşılmıştır. Ferreire (2019), Güney Afrika'da faaliyet gösteren bir yatırım şirketinin müşterileri üzerinde 
gerçekleştirdiği çalışmasında, kişiliğin finansal risk toleransı üzerine etkisini araştırmış ve farklı kişilik özelliklerine sahip bireylerin farklı finansal risk toleransı seviyelerine sahip oldukları ve deneyime daha açık olan bireylerin, diğer kişilik türlerine göre, daha yüksek risk tolerans düzeyine sahip oldukları bulgularına ulaşmıştır. Mathur ve Nathani (2019), çalışma hayatına yeni başlayan veya en fazla beş yıldır çalışan 22-27 yaş aralığındaki gençlerin kişilik özelliklerinin risk toleransı düzeyleri üzerindeki etkisini incelemişlerdir. Çalışmada; kadın ve erkeklerin risk toleransı düzeyleri arasında anlamlı bir farklılık olmadığı, beş faktör kişilik özelliklerinden uyumluluk, duygusal denge/dengesizlik ve deneyime açılık boyutları ile risk toleransı arasında güçlü bir ilişki olduğu, dışa dönüklük ve sorumluluk boyutları ile risk toleransı arasında ise bir ilişki olmadığ 1 bulgularına ulaşılmıştır.

Türkiye bazında, kişilik özellikleri ile finansal risk toleransı arasındaki ilişkiyi inceleyen sınırlı sayıda çalışmaya ulaşılabilmiştir. Temeloğlu ve Karaman (2014), Çanakkale ve Balıkesir'de faaliyet gösteren dört ve beş yıldızlı sayfiye otellerinde konaklayan turistler üzerine yaptıkları çalışmalarında, kişilik özellikleri ile algılanan risk arasında anlamlı ve pozitif bir ilişkinin olduğu sonucuna ulaşmışlardır. Kişilik özelliklerinin alt boyutları ile algılanan riskin alt boyutları değerlendirildiğinde, dışa dönüklük ile finansal risk, sosyal risk ve zaman riski arasında; uyumluluk ile zaman riski arasında; sorumluluk ile sosyal risk ve psikolojik risk arasında; duygusal denge ile performans riski, finansal risk, sosyal risk, psikolojik risk, zaman riski ve fiziksel risk arasında; yeniliklere açık olma ile performans riski, finansal risk ve sosyal risk arasında anlamlı ilişkiler bulunmuştur. Kübilay ve Bayrakdaroğlu (2016), yatırımcıların kişilik özellikleri, psikolojik önyargıları ve finansal risk toleransları arasındaki ilişkileri incelemek amacıyla yaptıkları çalışmalarında, kişilik özelliklerinin hem psikolojik önyargılar hem de finansal risk toleransı üzerinde etkili olduğu sonucuna ulaşmışlardır. Köylüoğlu vd. (2019), üniversite öğrencileri üzerine gerçekleştirdikleri çalışmalarında, kişilik özellikleri ile finansal iyilik hali ve risk alma tutumu arasındaki ilişkiyi incelemişlerdir. Çalışmada, cinsiyet faktörüne göre risk alma tutumu ve finansal iyilik hali arasında anlamlı farklılık olduğu, ayrıca risk alma tutumu ile kişiliğin deneyime açılık, uyumluluk ve dışa dönüklük boyutları arasında pozitif ve güçlü bir ilişki olduğu, risk alma tutumu ile kişiliğin nevrotiklik boyutu arasında negatif bir ilişki olduğu bulgularına ulaşılmıştır.

Literatürde beş faktör kişilik özelliklerinin finansal risk toleransı üzerindeki etkisini inceleyen çalışmalarda, görüldüğ̈ gibi, farklı bulgular söz konudur. Bir çalışmada kişiliğin belirli bir boyutunun finansal risk toleransı üzerindeki etkisi pozitif iken, farklı bir çalışmada negatif etkiye sahip olabilmekte veya hiçbir etkisi söz konusu olmayabilmektedir. Bu farklılıklar, finansal risk toleransının çok boyutlu bir yapısının olmasına bağlı olduğu gibi, örneklem, ölçek, yöntem gibi değişkenlere bağlı olarak da ortaya çıkabilmektedir. Bu durum, kişilik özelliklerinin finansal risk toleransı üzerindeki etkisini incelemeye yönelik yeni çalışmalara ihtiyaç olduğunu da göstermektedir.

\section{ARAŞTIRMANIN METEDOLOJISİ}

Çalışmanın bu bölümünde araştırmanın amacı, kapsamı, hipotezleri ve modeli ile verilerin toplanması ve analizine yer verilmiştir. 


\subsection{Araştırmanın Amacı Ve Kapsamı}

Bireylerin kendilerine özgü kişilik özelliklerinin finansal işlemlerinde alacakları kararlar üzerinde etkisi vardır. Bu kapsamda bireyler, bir yatırım kararı almadan önce karşılaşabilecekleri riskleri analiz ederler ve kendilerine uygun ise yatırım yapmaya karar verirler. Elbette, kişilik özelliklerinin dışında, risklerin değerlendirilmesinde ve finansal karar alma sürecinde etkili olan gelir, beklentiler, eğitim, finansal okuryazarlık gibi birçok faktör vardır. Fakat bu çalışmanın amacını, kişilik özellikleri ile finansal risk toleransı arasındaki ilişkinin incelenmesi oluşturmaktadır.

Araştırmanın kapsamını, Bursa Uludağ Üniversitesi İktisadi ve İdari Bilimler Fakültesi'nde (İ̈BF) üçüncü ve dördüncü sınıflarda okuyan öğrenciler oluşturmaktadır. Araştırmanın kapsamının, üçüncü ve dördüncü sınıflarda okuyan öğrencilerle kısıtlanmasının temel nedeni; finansal risk toleransı ölçeğinde yer alan bazı ifadelerin belli bir alan eğitimini tamamlamış bireyler tarafından daha kolay anlaşılabileceği ve eğitim düzeyine bağlı olası farklılıkları nispeten azaltma düşüncesidir.

\subsection{Araştırmanın Hipotezleri Ve Modeli}

Çalışmanın ana amacı olan beş faktör kişilik özellikleri ile finansal risk toleransı arasındaki ilişkilere yönelik, literatürden yararlanılarak aşağıdaki hipotezler oluşturulmuştur. $\mathrm{Bu}$ ana amacın dışında, demografik değişkenlere göre katılımcıların finansal risk toleransı düzeylerinin farklılık gösterip göstermediği de incelenmek istenmiş ve bu kapsamda hipotez 6 ve alt hipotezler de oluşturulmuştur.

$\mathrm{H}_{1}$ : Dışa dönüklük kişilik özelliğinin katılımcıların finansal risk toleransı düzeyleri üzerinde anlamlı ve pozitif bir etkisi vardır.

$\mathrm{H}_{2}$ : Uyumluluk kişilik özelliğinin katılımcıların finansal risk toleransı düzeyleri üzerinde anlamlı ve negatif bir etkisi vardır.

$\mathrm{H}_{3}$ : Sorumluluk kişilik özelliğinin katılımcıların finansal risk toleransı düzeyleri üzerinde anlamlı ve negatif bir etkisi vardır.

$\mathrm{H}_{4}$ : Duygusal denge/dengesizlik kişilik özelliğinin katılımcıların finansal risk toleransı düzeyleri üzerinde anlamlı ve pozitif bir etkisi vardır.

H5: Deneyime açıklık kişilik özelliğinin katılımcıların finansal risk toleransı düzeyleri üzerinde anlamlı ve pozitif bir etkisi vardır.

H6: Demografik faktörlere göre katılımcıların finansal risk toleransı düzeyleri arasında anlamlı bir farklılık vardır. vardır.

$\mathrm{H}_{6 a}$ : Yaşa göre katılımcıların finansal risk toleransları arasında anlamlı bir farklılık

H6b: Cinsiyete göre katılımcıların finansal risk toleransları arasında anlamlı bir farklılık vardır. 
Hoc: Ailenin aylık ortalama gelirine göre katılımcıların finansal risk toleransları arasında anlamlı bir farkl1lık vardır.

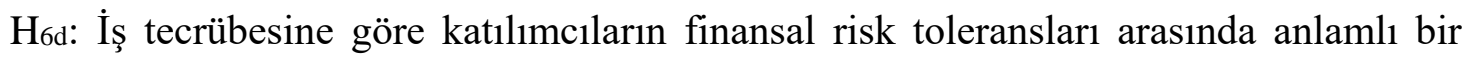
farklılık vardır.

H6e: Bölüme göre katılımcıların finansal risk toleransları arasında anlamlı bir farklılık vardir.

Hof: Sınıfa göre katılımcıların finansal risk toleransları arasında anlamlı bir farklılık vardir.

Beş faktör kişilik özelliklerinin ve demografik faktörlerin finansal risk tolerans1 üzerindeki etkilerini belirlemeye yönelik gerçekleştirilen çalışmanın modeli Şekil 1'de görülmektedir.

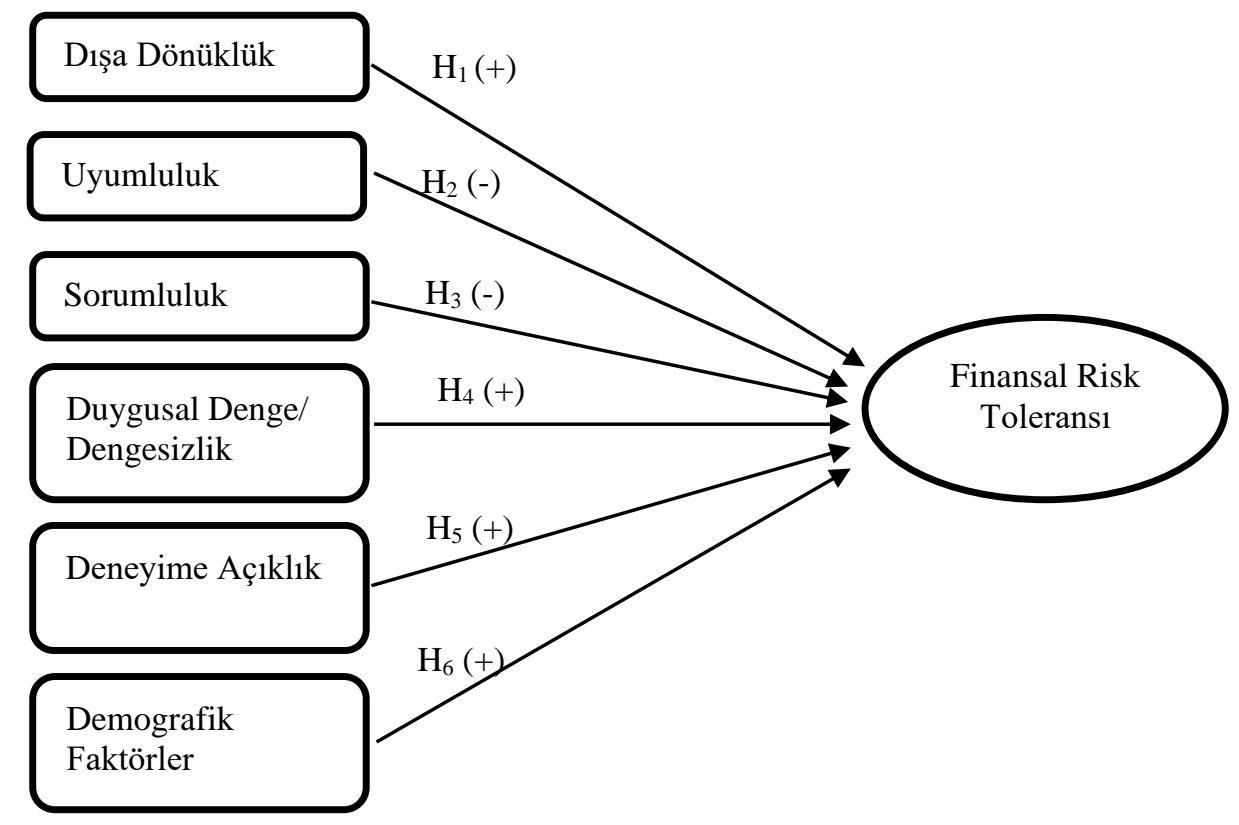

Şekil 1: Araştırma Modeli

\subsection{Verilerin Toplanması Ve Analizi}

Araştırmanın evrenini Bursa Uludağ Üniversitesi IIIBF'de okuyan üçüncü ve dördüncü sınıflarda okuyan öğrenciler oluşturmaktadır. 2019-2020 yılı verilerine, İiBF'de 5.950 kadın ve 7.685 erkek olmak toplam 13.635 öğrenci eğitim öğretim görmektedir (Bursa Uludağ Üniversitesi 2019 Yllı İdare Faaliyet Raporu). Kolayda örnekleme yöntemiyle üçüncü ve dördüncü sınıflarda okuyan 327 öğrenciden anket tekniği kullanılarak, Ekim 2019 itibariyle veri toplanmıştır. 
Verilerin toplanmasında kullanılan anket formu, üç bölümden oluşmaktadır. Birinci bölümde; cinsiyet, yaş, ailenin aylık ortalama geliri gibi katılımcıların demografik özelliklerine yönelik sorular yer almaktadır. İkinci bölümde; katılımcıların beş faktör kişilik boyutlarını ölçmek amacıyla, John vd. (1991) tarafindan geliştirilen, Türkçeye uyarlaması Sümer ve Sümer (2005) ve Karaman vd. (2010) tarafından yapılan beş faktör kişilik ölçeği yer almaktadır. Beş faktör kişilik ölçeği, beş alt boyuttan (dı̧̧a dönüklük, uyumluluk, sorumluluk, duygusal denge/dengesizlik ve deneyimlere açı olma) ve toplam 44 ifadeden oluşmaktadır. Beşli Likert tipi ölçekte, ifadeler " $1=$ Kesinlikle katılmıyorum, 5=Kesinlikle katılıyorum" olarak kodlanmıştır. Üçüncü bölümde; katılımcıların finansal risk toleransı düzeylerini ölçmek amaciyla Grable ve Lytton (1999) tarafindan geliştirilen ve 13 ifadeden oluşan "finansal risk toleransı ölçeği" kullanılmıştır. Yapılan güvenirlik analizi kapsamında, beş faktör kişilik ölçeğine ait Cronbach's Alpha katsayısı 0,67; finansal risk toleransı ölçeğine ait Cronbach's Alpha katsayısı 0,53 çıkmıştır.

Verilerin normal dağılım özelliği gösterip göstermediğini belirlemek amacıyla basıklık (kurtosis) ve çarpıklık (skewness) değerlerine bakılmıştır. Çarpıklık değeri, $-1,96$ ile $+1,96$ ve $\% 5$ anlamlılık seviyesinde normali gösterirken, +3 ile -3 arasındaki basıklık değerleri de $\% 5$ anlamlılık düzeyinde normal kabul edilmektedir (Uyar, 2019: 98). Bu bilgiler doğrultusunda araştırmanın veri setine ait çarpıklık değerleri -1 ile +1 arasında, basıklık değerleri -2 ile +2 arasında olduğundan normal dağılıma uygun olduğu sonucuna ulaşılmış̧ır. Veriler normal dağılım gösterdiği için verilerin analizinde, t-testi, tek yönlü varyans analizi (ANOVA) ve hiyerarşik regresyon analizi kullanılmıştır.

\section{BULGULAR}

Çalışmanın bu bölümünde araştırma bulgularına yer verilmiştir. Bu kapsamda, öncelikle katılımcıların demografik özelliklerine, sonrasında demografik faktörlere göre katılımcıların finansal risk toleransı düzeyleri arasında anlamlı bir farklılık olup olmadığını ortaya koymak amacıyla yapılan t-testi ve ANOVA analizlerinin sonuçlarına yer verilmiştir. Son olarak, değişkenler arasındaki ilişkileri belirlemek amacıyla yapılan korelasyon analizine ve beş faktör kişilik özelliklerinin finansal risk toleransı üzerindeki etkisini belirlemeye yönelik hiyerarşik regresyon analizine yer verilmiştir.

\subsection{Katılımcıların Demografik Özellikleri}

Tablo 1'de görüldüğü gibi, araştırmaya katılan katılımcıların \%63,6'sı kadınlardan, $\% 36,4$ 'ü erkeklerden oluşmaktadır. Yaş özelliklerine bakıldığında, katılımcıların yaşları 21 ve 22 yaşları arasında yoğunluk göstermektedir. Katılımcıların \%23,9'u İktisat, \%42,2'si Maliye, $\% 12,5$ 'i Ekonometri ve \%21,4'ü Çalışma Ekonomisi ve Endüstri İlişkileri (ÇEKO) bölümlerinde öğrenim görmektedir. Katılımcıların \%58,7'si normal öğrenimde, \% 41,3'ü ikinci öğrenimde eğitim görmektedir. Ankete katılan katılımcıların \%61,8'i üçüncü, \%38,2'si ise dördüncü sınıfta eğitim görmektedir. Katılımcıların $\% 33,9$ 'u bir iş tecrübesine sahip değilken, \%33,6's1 1 yıldan daha az, \%18'i 1-2 yıl arası, \%14,4'ü ise 3 yıl ve üzeri bir iş tecrübesine sahiptir. Katılımcıların ailelerinin gelir durumuna bakıldığında, katılımcıların $\% 55,7$ 'si, ailesinin aylık ortalama gelirinin 2.326-5.000 TL arasında olduğunu ifade etmiştir. 
Tablo 1. Katılımcıların Demografik Özellikleri

\begin{tabular}{|c|c|c|c|c|c|}
\hline Cinsiyet & $\mathbf{N}$ & $\%$ & Sinıf & $\mathbf{N}$ & $\%$ \\
\hline Kadın & 208 & 63,6 & 3. sinif & 202 & 61,8 \\
\hline Erkek & 119 & 36,4 & 4. sinif & 125 & 38,2 \\
\hline Toplam & 327 & 100 & Toplam & 327 & 100 \\
\hline Yaş & $\mathbf{N}$ & $\%$ & İş Tecrübesi & $\mathbf{N}$ & $\%$ \\
\hline 20 & 31 & 9,5 & İş tecrübem yok & 111 & 33,9 \\
\hline 21 & 125 & 38,2 & 1 yıldan daha az & 110 & 33,6 \\
\hline 22 & 104 & 31,8 & $1-2$ y1l aras1 & 59 & 18,0 \\
\hline 23 & 40 & 12,2 & 3 yıl ve üzeri & 47 & 14,4 \\
\hline 24 ve üzeri & 27 & 8,3 & Toplam & 327 & 100 \\
\hline Toplam & 327 & 100 & & & \\
\hline Bölüm & $\mathbf{N}$ & $\%$ & Ailenin Geliri & $\mathbf{N}$ & $\%$ \\
\hline İktisat & 78 & 23,9 & $1-2.325 \mathrm{TL}$ & 39 & 11,9 \\
\hline Maliye & 138 & 42,2 & $2.326-5.000 \mathrm{TL}$ & 182 & 55,7 \\
\hline Ekonometri & 41 & 12,5 & $5.001-7.500 \mathrm{TL}$ & 70 & 21,4 \\
\hline ÇEKO & 70 & 21,4 & 7.501 ve üzeri & 36 & 11,0 \\
\hline Toplam & 327 & 100 & Toplam & 327 & 100,0 \\
\hline Öğrenim Şekli & $\mathbf{N}$ & $\%$ & & & \\
\hline Örgün Öğr. & 192 & 58,7 & & & \\
\hline İkinci Öğr. & 135 & 41,3 & & & \\
\hline Toplam & 327 & 100 & & & \\
\hline
\end{tabular}

\subsection{Katılımcıların Finansal Risk Toleransı Düzeylerinin Demografik Faktörler Açısından İncelenmesi}

Yaş değişkenine göre katılımcıların finansal risk toleransı düzeyleri arasında anlamlı bir farklılı̆̆ın olup olmadığını test etmek için yapılan tek yönlü ANOVA analizinin sonuçları Tablo 2'de görülmektedir. Tablo 2'deki sonuçlar incelendiğinde, yaşa göre katılımcıların finansal risk toleransı düzeyleri arasında anlamlı bir farklılık bulunamamıştır $(F=1,933 ; p=$ $0,105>0,05)$.

Tablo 2. Yaş Değişkeni ANOVA Analizi Sonuçları

\begin{tabular}{|c|c|c|c|c|c|}
\hline Yaş & $\mathbf{N}$ & Ortalama & Standart Sapma & $\mathbf{F}$ & $\mathbf{p}$ \\
\hline 20 yaş veya altı & 31 & 2,2804 & 0,36436 & \multirow{5}{*}{1,933} & \multirow{5}{*}{0,105} \\
\hline 21 & 125 & 2,2031 & 0,33264 & & \\
\hline 22 & 104 & 2,1982 & 0,35254 & & \\
\hline 23 & 40 & 2,3231 & 0,37043 & & \\
\hline 24 yaş veya üzeri & 27 & 2,1111 & 0,35078 & & \\
\hline
\end{tabular}

Cinsiyete göre, katılımciların finansal risk toleransı düzeyleri arasında bir farklılık olup olmadığını belirlemek amacıyla yapılan bağımsız örneklem $t$ testinin Tablo 2'de görülen sonuçlarına göre, cinsiyetine göre katılımcıların finansal risk toleransları arasında anlamlı bir farklılık $(\mathrm{p}=0,000<0,05)$ söz konudur. Erkeklerin finansal risk toleransı düzeyleri, kadınlardan daha yüksektir. 
Tablo 3. Cinsiyet Değiş̧keni t-Testi Sonuçları

\begin{tabular}{|c|c|c|c|c|c|c|c|c|}
\hline & & & & & \multicolumn{4}{|c|}{ Levene Varyansların Eşitliği Testi } \\
\hline & Cinsiyet & $\mathbf{N}$ & Ortalama & Std. Sp. & $\mathbf{F}$ & $\mathbf{p}$ & $\mathbf{t}$ & $\mathbf{p}$ \\
\hline \multirow{2}{*}{$\begin{array}{c}\text { Finansal Risk } \\
\text { Toleransı }\end{array}$} & Kadın & 208 & 2,1616 & 0,33495 & \multirow[t]{2}{*}{0,565} & \multirow[t]{2}{*}{0,453} & $-3,784$ & \multirow[t]{2}{*}{$\mathbf{0 , 0 0 0}{ }^{*}$} \\
\hline & Erkek & 119 & 2,3109 & 0,35751 & & & $-3,717$ & \\
\hline
\end{tabular}

$* \mathrm{p}<0,05$

Ailenin aylık ortalama gelir seviyesi değişkenine göre, katılımcıların finansal risk toleransı düzeyleri arasında bir farklıı̆ı̆ın olup olmadığına ilişkin yapılan ANOVA analizinin sonuçları Tablo 4'te yer almaktadır. Analiz sonuçlarına göre, farklı gelir düzeylerine sahip katılımcılar arasında finansal risk toleransı açısından anlamlı bir farklılık olduğu $(F=3,789$; $\mathrm{p}=011<0,05)$ görülmektedir. Tukey HSD (Honestly Significant Difference) testi, ailesinin aylık ortalama geliri 1-2.325 TL arasında olanlar ile 5.001-7.500 TL arasinda olanlar ve 1$2.325 \mathrm{TL}$ arasında olanlar ile 7.501 TL ve üzeri olanlar arasında, yüksek gelir grupları lehine, anlamlı bir farklılığın olduğunu göstermektedir. Diğer bir deyişle, ailesinin aylık ortalama geliri daha yüksek olan katılımcıların finansal risk toleransı düzeyleri de daha yüksektir.

Tablo 4. Ailenin Geliri Değişkeni ANOVA Analizi Sonuçları

\begin{tabular}{|c|c|c|c|c|c|c|}
\hline Ailenin Geliri & $\mathbf{N}$ & Ortalama & Standart Sapma & $\mathbf{F}$ & $\mathbf{p}$ & Fark \\
\hline \multirow{4}{*}{$\begin{array}{l}\text { (1) } 1-2.325 \mathrm{TL} \\
\text { (2) } 2.326-5.000 \mathrm{TL} \\
\text { (3) } 5.001-7.500 \mathrm{TL} \\
\text { (4) } 7.501 \mathrm{TL} \text { ve üzeri }\end{array}$} & 39 & 2,1026 & 0,42549 & \multirow{4}{*}{$\begin{array}{l}3,78 \\
9\end{array}$} & \multirow{4}{*}{$\mathbf{0 , 0 1 1}$} & \multirow{4}{*}{$\begin{array}{l}1-3 \\
1-4\end{array}$} \\
\hline & 182 & 2,1923 & 0,33581 & & & \\
\hline & 70 & 2,2846 & 0,32408 & & & \\
\hline & 36 & 2,3248 & 0,34209 & & & \\
\hline
\end{tabular}

İş tecrübesi değişkenine göre katılımcıların finansal risk toleransı düzeyleri arasında bir farklılığın olup olmadığını belirlemek amacıyla yapılan ANOVA analizinin sonuçlarının yer aldığı Tablo 5'te görüldüğ̈̈ gibi, farklı iş tecrübesine sahip katılımcıların finansal risk toleransları arasında anlamlı bir farklılık $(F=2,475 ; \mathrm{p}=0,061>0,05)$ yoktur.

Tablo 5. İş Tecrübesi Değişkeni ANOVA Analizi Sonuçları

\begin{tabular}{|l|c|c|c|c|c|}
\hline İs Tecrübesi & $\mathbf{N}$ & Ortalama & Standart Sapma & F & p \\
\hline Yok & 111 & 2,1739 & 0,34909 & & \\
\cline { 1 - 4 } 1 yıldan daha az & 110 & 2,1895 & 0,34522 & \multirow{3}{*}{2,475} & \multirow{2}{*}{0,061} \\
\cline { 1 - 4 } 1-2 y1l aras1 & 59 & 2,2621 & 0,33289 & & \\
\hline 3 y1l ve üzeri & 47 & 2,3191 & 0,36925 & & \\
\hline
\end{tabular}

Katılımcıların eğitim gördükleri bölüme göre, katılımcıların finansal risk toleransı düzeyleri arasında bir farklılığın olup olmadığını belirlemeye yönelik yapılan ANOVA analizinin sonuçları Tablo 6'da yer almaktadır. Analiz sonuçlarına göre, farklı bölümlerde eğitim gören katılımcılar arasında finansal risk toleransı açısından anlamlı bir farklılık olduğu $(\mathrm{F}=3,439 ; \mathrm{p}=0,017<0,05)$ görülmektedir. Tukey HSD testi, Maliye bölümünde eğitim görenler ile Ekonometri bölümünde eğitim görenlerin finansal risk toleransı düzeyleri arasında anlamlı bir farklılığın olduğunu göstermektedir. Buna göre, Ekonometri bölümünde 
eğitim gören katılımcıların finansal risk toleransları, Maliye bölümünde eğitim görenlerden daha yüksektir.

Tablo 6. Bölüm Değişkeni ANOVA Analizi Sonuçları

\begin{tabular}{|l|c|c|c|c|c|c|}
\hline Bölüm & $\mathbf{N}$ & Ortalama & Standart Sapma & F & p & Fark \\
\hline (1) İktisat & 78 & 2,2525 & 0,34264 & & & \\
\cline { 2 - 5 } (2) Maliye & 13 & 2,1466 & 0,34712 & & & \\
(3) Ekonometri & 8 & & \multirow{2}{*}{3,439} & $\mathbf{0 , 0 1 7}$ & $2-3$ \\
\cline { 2 - 5 } (4) ÇEKO & 41 & 2,3077 & 0,35082 & & & \\
\cline { 2 - 5 } & 70 & 2,2582 & 0,34650 & & & \\
\hline p $<0,05$
\end{tabular}

Katılımcıların okudukları sınıfa göre finansal risk toleransı düzeyleri arasında bir farklılık olup olmadığını belirlemek amacıyla yapılan t-testinin Tablo 7'de yer alan sonuçlarına göre, katılımcıların okudukları sınıfa finansal risk toleransları arasında anlamlı bir farklilik $(\mathrm{p}=0,585>0,05)$ yoktur.

Tablo 7. Sınıf Değişkeni t-Testi Sonuçları

\begin{tabular}{|c|c|c|c|c|c|c|c|c|}
\hline & \multicolumn{8}{|c|}{ Levene Varyansların Eşitliği Test } \\
\hline & Sinıf & $\mathbf{N}$ & Ortalama & Std. Sp. & $\mathbf{F}$ & $\mathbf{p}$ & $\mathbf{t}$ & $\mathbf{p}$ \\
\hline \multirow{2}{*}{$\begin{array}{c}\text { Finansal Risk } \\
\text { Toleransı }\end{array}$} & 3. sinif & 202 & 2,2243 & 0,35086 & \multirow[t]{2}{*}{0,003} & \multirow[t]{2}{*}{0,957} & 0,547 & \multirow[t]{2}{*}{0,585} \\
\hline & 4. $\sin 1 f+$ & 125 & 2,2025 & 0,35027 & & & 0,547 & \\
\hline
\end{tabular}

Yapılan t-testleri ve ANOVA analizleri, $\mathrm{H}_{6 b}, \mathrm{H}_{6 c}$ ve $\mathrm{H}_{6 \mathrm{ce}}$ hipotezlerinin desteklendiğini, buna karşın, $\mathrm{H}_{6 \mathrm{a}}, \mathrm{H}_{6 \mathrm{~d}}$ ve $\mathrm{H}_{6 \mathrm{f}}$ hipotezlerinin desteklenmediğini göstermektedir.

\subsection{Korelasyon Analizi}

Finansal risk toleransı ile beş faktör kişilik özellikleri arasındaki ilişkileri incelemek amacıyla yapılan Pearson korelasyon analizi sonuçlarına göre, finansal risk toleransı ile duygusal denge/dengesizlik kişilik özelliği arasında, 0,01 anlamlılık düzeyinde zayıf, negatif ve anlamlı bir ilişki, finansal risk toleransı ile deneyime açıklık kişilik özelliği arasında, 0,01 anlamlılık düzeyinde zayıf, pozitif ve anlamlı bir ilişki olduğu görülmektedir. Korelasyon analizi sonuçları Tablo 8'de yer almaktadır.

Tablo 8. Değişkenler Arasındaki Korelasyonlar

\begin{tabular}{|c|c|c|c|c|c|c|}
\hline & (1) & (2) & (3) & (4) & (5) & (6) \\
\hline (1) Finansal Risk Tolerans1 & 1 & & & & & \\
\hline (2) Dişa Dönüklük & $-0,011$ & 1 & & & & \\
\hline (3) Uyumluluk & $-0,001$ & $0,285 * *$ & 1 & & & \\
\hline (4) Sorumluluk & $-0,013$ & $0,234 * *$ & $0,282 * *$ & 1 & & \\
\hline $\begin{array}{l}\text { (5) Duygusal } \\
\text { Denge/Dengesizlik }\end{array}$ & $-0,145^{* *}$ & 0,026 & $0,164 * *$ & $0,151^{* *}$ & 1 & \\
\hline (6) Deneyime Açıklık & $0,149 * *$ & $0,163 * *$ & $0,288 * *$ & $0,220 * *$ & 0,001 & 1 \\
\hline
\end{tabular}




\subsection{Hiyerarşik Regresyon Analizi Sonuçları}

Beş faktör kişilik özelliklerinin finansal risk toleransı üzerindeki etkisini belirlemek amacıyla lojistik regresyon analizi kullanılmıştır. Regresyon analizinde, finansal risk toleransı bağımlı değişken olarak, beş faktör kişilik özellikleri (dışadönüklük, sorumluluk, uyumluluk, duygusal denge/dengesizlik, deneyime açıklık) bağımsız değişkenler olarak ve demografik faktörler kontrol değişkenleri olarak ele alınmıştır.

Analiz iki aşamada gerçekleştirilmiş̧ir. Birinci aşamada demografik faktörler modele dahil edilmiştir. İkinci aşamada ise, kişilik özellikleri modele dahil edilerek, bu özelliklerin finansal risk toleransı üzerindeki etkisi belirlenmeye çalışılmıştır.

Hiyerarşik regresyon analizinde, ilk olarak modelin regresyon analizinin varsayımlarını karşılayıp karşılamadığ 1 incelenmiştir. Hata terimleri arasında ardışı bağımlılık (iliş̧ki/otokorelasyon) olmadığını ortaya koyan Durbin-Watson katsayısı 1,5 ile 2,5 arasında bir değer almalıdır (Kalaycı, 2014: 264). Veri setine ait Durbin-Watson katsayısı bu kritere uygun olarak 2,005 olarak bulunmuştur. Regresyon analizinde, tolerans değerinin 0,20'den büyük olmasi; VIF (Varyans Artış Faktörü) değerinin 10'dan büyük olması çoklu bağlantı olmadığını göstermektedir (Albayrak, 2005: 110). Modelin tolerans değerleri 0,810'dan büyük ve VIF değerleri 1,047-1,235 arasında değerler aldığından, bağımsız değişkenler arasında çoklu bağlantı sorunu yoktur.

Tablo 9. Hiyerarşik Regresyon Analizi Sonuçları

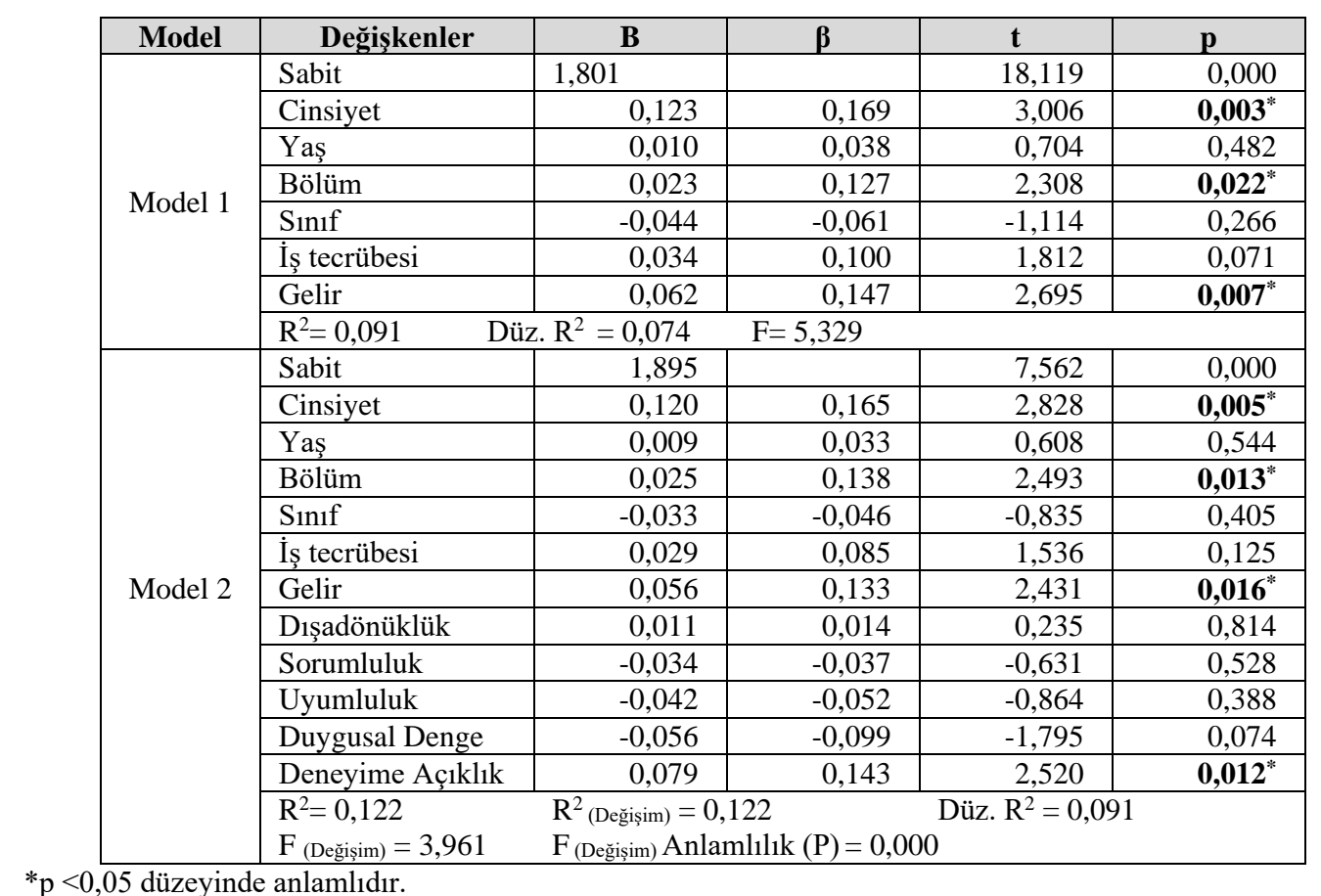

Hiyerarşik regresyon analizinin sonuçları Tablo 9'da görülmektedir. Tablo incelendiğinde Model 1'de ulaşılan sonuçlara göre demografik değişkenlerden cinsiyet, bölüm ve gelir değişkenleri finansal risk toleransı üzerinde anlamlı ve pozitif bir etkiye sahiptir. Diğer taraftan, yaş, sınıf ve iş tecrübesi değişkenlerinin finansal risk toleransı 
üzerinde anlamlı bir etkiye sahip olmadığı görülmektedir. $F=5,329$ ve $p=0,000$ değerleri Model 1'in anlamlı olduğunu göstermektedir. Ayrıca demografik değişkenler finansal risk toleransındaki değişimin \%7,4'ünü açıklamaktadır (Düz. $\mathrm{R}^{2}=0,074$ ). Model 1'e ait $\beta$ değerleri finansal risk toleransı üzerinde en fazla cinsiyet değişkeninin etkiye sahip olduğunu, bunu gelir ve bölüm değişkenlerinin izlediğini göstermektedir.

Hiyerarşik regresyon analizinde Model 1'e kişilik özellikleri dahil edilerek Model 2 elde edilmiştir. Genel bir ifadeyle, Model 2 anlamlı $(F=3,961$ ve $p=0,000)$ olup, demografik özellikler ve kişilik özellikleri finansal risk toleransının \%9,1'ini açılamaktadır (Düz. $\mathrm{R}^{2}=$ 0,091). Kişilik özelliklerinin analize dahil edilmesiyle açıklanan varyansta meydana gelen değişim yaklaşık \%2 olmuştur. Bu sonuç, kişilik özelliklerinin, genel olarak, finansal risk toleransı üzerinde anlamlı ama küçük bir etkisinin olduğunu göstermektedir. Model 2'deki sonuçlara bakıldığında, kişilik özelliklerinden deneyime açıklık boyutunun finansal risk toleransı üzerinde anlamlı ve pozitif bir etkiye sahip olduğu, kişiliğin diğer boyutlarının (dışa dönüklük, sorumluluk, uyumluluk, duygusal denge/dengesizlik) ise anlamlı bir etkisinin olmadığ 1 görülmektedir. Bu sonuçlar, deneyime ve yeniliklere daha açık olan bireylerin finansal risk toleransı düzeylerinin daha yüksek olduğunu göstermektedir. Diğer bir deyişle, daha merakl, ilgili, yeni fikirlere ve deneyimlere açı olan, tutucu olmayan bireylerin finansal risk toleransı düzeyleri, deneyime daha az açık (veya kapalı) olan bireylerden daha yüksektir.

Model 2'den elde edilen bulgular, Hipotez 5'in desteklendiğini, Hipotez 1, 2, 3 ve 4'ün desteklenmediğini göstermektedir.

\begin{tabular}{|l|l|}
\hline Hipotez & Sonuç \\
\hline $\begin{array}{l}\mathrm{H}_{1} \text { : Dışa dönüklük kişilik özelliğinin katılımcıların finansal risk } \\
\text { toleransı düzeyleri üzerinde anlamlı ve pozitif bir etkisi vardır. }\end{array}$ & Desteklenmedi \\
\hline $\begin{array}{l}\mathrm{H}_{2} \text { : Uyumluluk kişilik özelliğinin katılımcıların finansal risk toleransı } \\
\text { düzeyleri üzerinde anlamlı ve negatif bir etkisi vardır. }\end{array}$ & Desteklenmedi \\
\hline $\begin{array}{l}\mathrm{H}_{3} \text { : Sorumluluk kişilik özelliğinin katılımcıların finansal risk toleransı } \\
\text { düzeyleri üzerinde anlamlı ve negatif bir etkisi vardır. }\end{array}$ & Desteklenmedi \\
\hline $\begin{array}{l}\text { H4: Duygusal denge/dengesizlik kişilik özelliğinin katılımcıların } \\
\text { finansal risk toleransı düzeyleri üzerinde anlamlı ve pozitif bir etkisi } \\
\text { vardır. }\end{array}$ & Desteklenmedi \\
\hline $\begin{array}{l}\text { H5: Deneyime açıklık kişilik özelliğinin katıllımcıların finansal risk } \\
\text { toleransı düzeyleri üzerinde anlamlı ve pozitif bir etkisi vardır. }\end{array}$ & Desteklendi \\
\hline
\end{tabular}

\section{SONUÇ}

Bir bireyin finansal risk toleransı ile bireyin finansal tutum ve davranışları arasında bir iliş̧i vardır. Diğer bir deyişle, bireyin finansal risk toleransı düzeyinin alacağı finansal kararlar üzerinde bir etkisi söz konudur. $\mathrm{Bu}$ nedenle, finansal risk toleransının belirleyicilerinin araştırılması hem araştırmacıların hem de uygulayıcıların (portföy yöneticileri, finansal danışmanlar vb.) ilgisini çeken konulardan biri olmuştur. Finansal risk toleransını etkileyen birçok faktör olmakla birlikte, önemli faktörlerden biri de bireyin sahip olduğu kişilik özellikleridir. Bu çalışmanın amacı, kişilik özelliklerinin finansal risk toleransı 
üzerindeki etkisini incelemektir. Kişilik modelleri arasında yaygın kabul gören beş faktör kişilik modeli kullanılmıştır. Bu model, kişilik özelliklerini dışa dönüklük, uyumluluk, sorumluluk, duygusal denge/dengesizlik ve deneyime açıklık olmak üzere beş alt boyut altında toplamaktadır.

Çalışmada ilk olarak, demografik faktörlere göre katılımcıların finansal risk toleransı düzeyleri arasında anlamlı bir farklılık olup olmadığını belirlemek amacıyla t-testi ve ANOVA analizi yapılmıştır. Analiz sonuçlarına göre, yaş, iş tecrübesi ve sınıf değişkenlerine göre katılımcıların finansal risk toleransı düzeyleri arasında anlamlı bir farklılık söz konusu değil iken, cinsiyet, gelir ve bölüm değişkenlerine göre anlamlı bir farklılık bulunmuştur. Buna göre, erkekler kadınlardan daha yüksek finansal risk toleransı derecesine sahiptir. Ailesinin aylık ortalama geliri daha yüksek olanların, ailesinin aylık ortalama geliri düşük olanlara göre, finansal risk toleransları daha yüksektir. Bölüm değişkeni açısından, Ekonometri bölümünde eğitim alan katılımcıların finansal risk toleransları, Maliye bölümünde eğitim alan katılımcıların finansal risk toleranslarından daha yüksektir. Bu çalışmada, yaş ve iş tecrübesi değişkenlerine göre katılımcıların finansal risk toleransları arasında bir farklılık olmadığı bulgusuna ulaşılmıştır. Katılımcıların yaş aralığının dar olması (ağırlıklı olarak 21-23 yaş aralığı) nedeniyle, yaşın finansal risk toleransı üzerindeki etkisi görülememiş olabilir. Benzer şekilde, katılımcıların yaklaşık \%34'ünün iş tecrübesine sahip olmaması (çalışmamış veya çalışmıyor olması), \%52'sinin 1 yıldan az veya $1-2$ yıl arasında kısa bir iş tecrübesine sahip olması (çalışmış veya çalışıyor olması) nedeniyle, iş tecrübesinin finansal risk toleransı üzerinde bir etkisinin ortaya çıkmadığ Katılımcıların okudukları sınıf (birinci sınıf, ikinci sınıf gibi) genellikle yaş ve aldıkları eğitim nedeniyle finansal risk toleransı üzerinde dolaylı bir etkiye sahip olabilmektedir. Fakat çalışmanın kapsamını üçüncü ve dördüncü sınıflar oluşturduğu için sınıf değişkenine göre anlamlı bir farklılık ortaya çıkmamıştır. Çalışmanın kapsamına birinci ve ikinci sınıflar da dahil edilmiş olsaydı, yukarıda ifade edildiği gibi, yaşın ve görülen eğitimin dolaylı etkisiyle, sınıf değişkenine göre anlamlı bir farklılığın ortaya çıkması beklenebilirdi.

Kişilik özelliklerinin finansal risk toleransı üzerindeki etkisini belirlemek amacıyla hiyerarşik regresyon analizi yapılmıştır. Analiz sonuçları, kişilik özelliklerinden sadece deneyime açıklık boyutunun finansal risk toleransı üzerinde anlamlı ve pozitif bir etkisinin olduğunu, diğer kişilik boyutlarının (dışa dönüklük, uyumluluk, sorumluluk ve duygusal denge/dengesizlik) finansal risk toleransı üzerinde istatistiksel olarak anlamlı bir etkisinin olmadığını göstermektedir. Buna göre, deneyime ve yeniliklere açık bireyler, deneyime açık olmayan bireylere göre daha yüksek finansal risk toleransına sahiptirler. Önceki çalışmalarda da deneyime açıklık boyutunun finansal risk toleransı üzerinde pozitif bir etkisinin olduğuna ilişkiler bulgulara ulaşılmıştır. Bu açıdan, bu çalışmanın bulguları literatür ile uyumludur. Literatürde iki veya daha fazla, hatta beş kişilik boyutunun tamamının finansal risk toleransıyla ilişkili (pozitif veya negatif yönde) olduğuna ilişkin bulgular da olmakla birlikte, bu çalışmada kişiliğin sadece tek boyutunun finansal risk toleransıyla ilişkili olduğu bulunmuştur.

$\mathrm{Bu}$ çalışmanın en önemli kısıtı, araştırmanın kapsamına sadece bir fakültenin üç bölümünde, üçüncü ve dördüncü sınıflarda okuyan öğrencilerin dahil edilmesidir. Üniversite, fakülte, bölüm ve sınıf açılarından araştırmanın evreni genişletilerek daha büyük örneklem kullanılarak yapılacak çalışmalar hem demografik özelliklerin hem de kişilik özelliklerinin finansal risk toleransı üzerindeki etkilerinin değerlendirilmesine katkı sağlayacaktır. Ayrıca 
nispeten benzer demografiklere (yaş, medeni durum, çalışma/iş tecrübesi durumu gibi) sahip öğrenciler dışında, hane halkı üzerinde yapılacak çalışmalar da literatüre katkı sağlayacaktır.

\section{KAYNAKLAR}

Alarcon, Gene - Eschleman, Kevin - Bowling, Nathan (2009), "Relationships Between Personality Variables and Burnout: A Meta-analysis", Work \& Stress, 23(3), pp. 244263.

Albayrak, Ali Sait (2005), "Çoklu Doğrusal Bağlantı Halinde En Küçük Kareler Tekniğinin Alternatifi Yanlı Tahmin Teknikleri ve Bir Uygulama”, ZKÜ Sosyal Bilimler Dergisi, 1(1), ss. 105-126.

Anastasia, Njo - Malelak, Mariana Ing (2019), "Effects of Personality Trait in Financial Risk Tolerance Investor in Surabaya". In: The 3rd International Conference Postgraduate School - ICPS 2019, 30-07-2019 - 30-07-2019, Surabaya - Indonesia.

Anbar, Adem - Eker, Melek (2009), "Bireysel Yatırımcıların Finansal Risk Algılamalarını Etkileyen Demografik ve Sosyoekonomik Faktörler", ZKÜ Sosyal Bilimler Dergisi, 5(9), ss. 129-150.

Baffour, Priscilla Twumasi - Mohammed, Ibrahim - Rahaman, Wassiuw Abdul (2019), "Personality and Gender Differences in Revealed Risk Preference: Evidence from Ghana”, International Journal of Social Economics, 46(5), pp. 631-647.

Bursa Uludağ Üniversitesi 2019 Y1lı İdare Faaliyet Raporu, http://www.sp.gov.tr/upload/xSPRapor/files/J11ou+Uludag_19_FR.pdf (Erişim Tarihi: 25.03.2020).

Ceyhan, Gökşen (2008), "Yaşam Biçimlerinin Finansal Risk Toleransına Olan Etkileri Üzerine Bir Uygulama" Hacettepe Üniversitesi Sosyal Bilimler Enstitüsü, Yüksek Lisans Tezi, Ankara.

Chaulk, Barbara - Johnson, Phyllis J. - Bulcroft, Richard (2013), "Effects of Marriage and Children on Financial Risk Tolerance: A Synthesis of Family Development and Prospect Theory", Journal of Family and Economic Issues, 24(3), pp. 257-279.

Costa, Paul T. - McCrae, Robert R. - Dye, David A. (1991), "Facet Scales for Agreeableness and Conscientiousness: A Revision of The Neo Personality Inventory", Personality and Individual Differences, 12(9), pp. 887-898.

Czerwonka, Monika (2019), "Cultural, Cognitive and Personality Traits in Risk Taking Behaviour: Rvidence from Poland and the United States of America", Economic Research Ekonomska Istraživanja, 32(1), pp. 894-908.

Çelebi, Nurhayat - Uğurlu, Baran (2014), "Resmi Liselerde Çalışan Öğretmenlerin Kişilik Özelliklerinin Demografik Değişkenlere Göre İncelenmesi”, Adıyaman Üniversitesi Sosyal Bilimler Enstitüsü Dergisi, 7(18), ss. 537-569. 
Demireli, Erhan (2007), "Finansal Yatırım Kararlarında Risk Unsuru ve Riske Maruz Değer", Dokuz Eylül Üniversitesi Sosyal Bilimler Enstitüsü Dergisi, 9(1), ss. 122-134.

Deniz, Arzu - Erciş, Aysel (2008), "Kişilik Özellikleri İle Algılanan Risk Arasındaki İlişkilerin İncelenmesi Üzerine Bir Araştırma", Atatürk Üniversitesi İktisadi ve İdari Bilimler Dergisi, 22(2), 301-330.

Dickason, Zandri - Ferreira, Sune (2018), "Establishing a Link Between Risk Tolerance, Investor Personality and Behavioural Finance in South Africa", Cogent Economics \& Finance, 6, 1519898.

Dinç Aydemir, Sibel - Aren, Selim, (2016), "Bireylerin Risk Azaltma Stratejilerini Etkileyen Faktörler Üzerine Ampirik Bir Araştırma", Maliye Finans Yazıları, 105, ss. 75-92.

Dinç, Mehmet - Bitlisli, Ferhat - Çetinceli, Esra - Aydın, Sonay Zeki (2013), "Öğretim Elemanlarının Tükenmişliğinde Beş Faktör Kişilik Özelliklerinin Etkisi: Süleyman Demirel Üniversitesi Meslek Yüksekokulları Örneği”, Süleyman Demirel Üniversitesi Vizyoner Dergisi, 4(9), ss.44-69.

Dorn, Daniel - Huberman, Gur (2005), "Talk and Action: What Individual İInvestors Say and What They Do?", Review of Finance, 9(4), pp. 437-481.

Erkuş, Ahmet - Tabak, Akif (2009), "Beş Faktör Kişilik Özelliklerinin Çalışanların Çatışma Yönetim Tarzlarına Etkisi: Savunma Sanayiinde Bir Araştırma”, Atatürk Üniversitesi İktisadi ve İdari Bilimler Dergisi, 23(2), ss. 213-242.

Eroğluer, Kemal - Kahraman, Çağdaş Akif (2019), "Çalışanların Kişilik Özelliklerinin İșe Cezbolma Algıları Üzerine Etkisi: Bir Firma Uygulaması", Gazi İktisat ve İşletme Dergisi, 5(1), ss. 21- 33.

Ferreira, Susara Johanna (2019), "Is Financial Risk Tolerance Influenced By Personality Traits?", 27 August 2019, 12th Economics \& Finance Conference, Dubrovnik ISBN 978-80-87927-80-9, IISES.

Fisher, Patti J. - Yao, Rui (2017), "Gender Differences in Financial Risk Tolerance", Journal of Economic Psychology, 61, pp. 191-202.

Gilliam, John - Chatterjee, Swarn - Grable, John (2010), "Measuring the Perception of Financial Risk Tolerance: A Tale of Two Measures", Journal of Financial Counseling and Planning, 21(2), pp. 40-53.

Golberg, Lewis R. (1990), “An Alternative "Description of Personality": The Big-Five Factor Structure", Journal of Personality and Social Psychologs, 59(6), pp. 1216-1229.

Grable, John - Lytton, Ruth H. (1999), "Financial Risk Tolerance Revisited: The Development of a Risk Assessment Instrument", Financial Services Review, 8, pp. 163-181. 
Grable, John (2000), "Financial Risk Tolerance and Additional Factors That Affect Risk Taking in Everyday Money Matters", Journal of Business and Psychology, 14(4), pp. 625-630.

Grable, John E. - Joo, So-Hyun (2004), "Environmental and Biopsychosocial Factors Associated with Financial Risk Tolerance", Journal of Financial Counseling and Planning, 15(1), pp. 73-82.

Hallahan, Terrence - Faff, Robert - Mckenzie, McKenzie (2003), “An Exploratory Investigation of The Relation Between Risk Tolerance Scores and Demographic Characteristics", Journal of Multinational Financial Management, 13(4-5), pp. 483502 .

Hoffmann, Arvid O. I. - Post, Thomas - Pennings, Joost M. E. (2015), "How Investor Perceptions Drive Actual Trading and Risk-Taking Behavior", Journal of Behavioral Finance, 16(1), pp. 94-103.

Horzum, Mehmet Barış - Ayas, Tuncay - Padır, Mehmet Ali (2017), "Beş Faktör Kişilik Ölçeğinin Türk Kültürüne Uyarlanması", Sakarya University Journal of Education, 7(2), ss. 398-408.

Howard, Pierce J. - Howard, Jane M. (1998), "The Big Five Quickstart an Introduction to The Five Factor Model of Personality For Human Resource Professionals", Charlotte, NC: Centre for Applied Cognitive Studies.

İçerli, Leyla - Uğuz Arsu, Şerife (2019), "Beş Faktör Kişilik Özelliklerinin Kariyer Değerleri Üzerindeki Etkisi: Üniversite Öğrencileri Üzerine Bir Araştırma”, İktisadi İdari ve Siyasal Araştırmalar Dergisi, 4(8), ss. 21-45.

Jameel, Qurat-ul-ain - Siddiqui, Danish Ahmed (2019), "Effect of Demographics, Personality Traits, and Financial Literacy on Risk Tolerance and Behavioral Biases in Individual Investors of Pakistan Stock Exchange", Electronic copy available at: https://ssrn.com/abstract=3510620.

John, Oliver P. - Donahue, Eileen M. - Kentle, Robert L. (1991), The Big-Five InventoryVersion 4a and 54. CA, Berkeley: Berkeley Institute of Personality and Social Research.

Kalaycı, Şeref (2014), SPSS Uygulamalı Çok Değişkenli İstatistik Teknikleri, Asil Yayın Dağıtım, Ankara.

Karaman, Neslihan Güney - Dogan, Turkan - Coban, Aysel Esen (2010), “A Study to Adapt The Big Five Inventory to Turkish", Procedia Social and Behavioral Sciences, 2, pp. 2357-2359.

Kourtidis, Dimitrios - Chatzoglou, Prodromos - Sevic, Zeljko (2017), The Role of Personality Taits in Investors Trading Behaviour: Empirical Evidence from Greek", International Journal of Social Economics, 44(11), pp. 1402-1420. 
Köylüoğlu, A. Selçuk - Gümrah, Abdurahman - Doğan, Mesut (2019), “Tüketicilerin Kişilik Özellikleri ile Finansal İyilik Hâli ve Risk Alma Tutumu Arasındaki İlişki”, Selçuk Üniversitesi Sosyal Bilimler Meslek Yüksekokulu Dergisi, 22(2), ss. 903-913.

Kuzniak, Stephen - Grable, John E. (2017), "Does Financial Risk Tolerance Change over Time? A Test of The Role Macroeconomic, Biopsychosocial and Environmental, and Social Support Factors Play in Shaping Changes in Risk Attitudes", Financial Services Review, 26, pp. 315-338.

Kübilay, Bilgehan - Bayrakdaroğlu, Ali (2016), "An Empirical Research on Investor Biases in Financial Decision-Making, Financial Risk Tolerance and Financial Personality", International Journal of Financial Research, 7(2), pp. 171-182.

Mathur, Garima - Nathani, Navita (2019), "Personality Traits and Risk Tolerance among Young Investors", International Journal of Innovative Technology and Exploring Engineering (IJITEE), 8(10), pp. 2019-2013.

Nitelik Ödemiş, Sibel (2011), "Beş Faktör Kişilik Özelliklerinin Üretkenlik Karşııtı Davranışlar Üzerine Etkileri: Bir Araştırma", Marmara Üniversitesi Sosyal Bilimler Enstitüsü, Yüksek Lisans Tezi, İstanbul.

Pak, Olga - Mahmood, Monowar (2013), "Impact of Personality on Risk Tolerance and Investment Decisions", International Journal of Commerce and Management, 25(4), pp. 370-384.

Paksoy, H. Mustafa - Özbezek, B. Dilek - Gül, Meryem (2019), "Kişilik Özellikleri ve Davranışsal Finans: Üniversite Öğrencileri Üzerine Bir Araştırma”, International Social Sciences Studies Journal, 5(40), ss. 3861-3878.

Pinjisakikool, Teerapong (2017), “The Influence of Personality Traits on Households' Financial Risk Tolerance and Financial Behaviour", Journal of Interdisciplinary Economics, 30(1), 32-54.

Rabbani, Abed G. - Yao, Zheying - Wang, Christina (2019), "Does Personality Predict Financial Risk Tolerance of Pre-Retiree Baby Boomers?", Journal of Behavioral and Experimental Finance, 23, pp. 124-132.

Roberts, Brent W. (2009). Back to the Future: Personality and Assessment and Personality Development", Journal of Research in Personality, 43(2), pp. 137-145.

Seibert, Scott E. - Kraimer, Maria L. (2001), "The Five-Factor Model of Prsonality and Career Success", Journal of Vocational Behavior, 58(1), pp. 1-21.

Somer, Oya - Korkmaz, Mediha - Tatar, Arkun (2002), "Beş Faktör Kişilik Envanteri'nin Geliştirilmesi-I: Ölçek ve Alt Ölçeklerin Oluşturulması” Türk Psikoloji Dergisi, $17(49)$, ss. $21-33$.

Sümer, Nebi - Sümer, H. Canan (2005). Beş Faktör Kişilik Özellikleri Ölçeği. Yayımlanmamış Çalışma. 
Tatar, Arkun - Bildik, Tezan - Saltukoğlu, Gaye - Dinçel, Münevver Güler (2014), "Klinik Olmayan Örneklemde Beş Faktör Kişilik Envanteri Belirti Tarama Amaçlı Kullanılabilir mi?: Ön Çalışma", FSM İlmî Araştırmalar İnsan ve Toplum Bilimleri Dergisi, 4, ss. 181 - 199.

Temeloğlu, Erdem - Karaman, Sebahattin (2014), “Tüketicilerin Kişilik Özelliklerine Göre Algıladıkları Risk Türlerini Belirlemeye Yönelik Bir Araştırma: Dört ve Beş Yıldızlı Otel İşletmelerinde Bir Uygulama", Balıkesir Üniversitesi, Bandırma İ.̇̇.B.F. 9. International Conferance: New Perspectives in Tourism and Hospitality, ISBN : 978975-6993-19-4.

Türk Dil Kurumu (TDK) Sözlüğü, https://sozluk.gov.tr/

Uyar, Metin (2019), "Maliyet Yapısı, Yönetim Muhasebesi ve Üretim Performansı İlişkisi", Muhasebe Bilim Dünyası Dergisi, 21(1), ss. 89-120.

Van de Venter, Gerhard - Michayluk, David - Davey, Geoff (2012), "A Longitudinal Study of Financial Risk Tolerance”, Journal of Economic Psychology, 33, pp. 794-800.

Wong, Alan - Carducci, Bernardo (2013), "Does Personality Affect Personal Financial Risk Tolerance Behavior?", The IUP Journal of Applied Finance, 19(3), pp. 5-18.

Yao, Rui - Hanna, Sherman D. (2005), "The Effect of Gender and Marital Status on Financial Risk Tolerance", Journal of Personal Finance, 4(1), pp. 66-85. 
